Vol. XiI. NO. 4.-BOTANiCAL GazetTe.-ApRIL. 1887.

\title{
Notes on Umbelliferæ of E. United States. III.
}

\author{
JOHN M. COULTER AND J. N. ROSE.
}

(WITH PLATE III.)

The range of Erigenia bulbosa, as given on page $\mathrm{I}_{5}$, ante, should be somewhat extended, so as to include Eastern Pennsylvania, along the Lower Susquehanna (Porter), and Tennessee (Gattinger). It is very much desired that botanists will not only assist us in thus perfecting the range of our species of Umbelliferæ, but also in providing good fruiting specimens. The failure of many of our best collections in fruiting specimens is somewhat remarkable, and we give this early notice, that all collectors, western as well as eastern, may take pains during the coming season to collect fruiting specimens of all the Umbelliferæ of their region. We already have to acknowledge the courtesy which has extended to us all needed assistance from the Harvard Herbarium and from the herbaria of I. C. Martindale, Thomas C. Porter, M. S. Bebb, Wm. M. Canby, Walter Deane, and S. M. Tracy.

LIGUSTICUM L.-Fruit ovate to oblong, not flattened either way: carpel with 5 equal strong primary ribs (sometimes winged), each with a group of strengthening cells : oil-ducts $2-4$ in the intervals, 6 on the commissural side: seed-section somewhat dorsally flattened: stylopodium conical (figs. 27-30). - Smooth perennials, with aromatic roots and fruit, 2-3 ternately compound leaves, and white flowers.

I. L. Scoticum L. Spec. 25o. Stem simple, I-2 ft. high: leaves twice ternate; leaflets ovate, coarsely toothed; fruit narrowly oblong, 4-5 lines long; oil-ducts small, 2-3 in the intervals ; seed-section nearly semicircular (figs. 27, 28).Salt marshes, New England. Fl. August.

2. L. actæifolium Michx. Fl. i. I66. Stem branched above, $2-6 \mathrm{ft}$. high: leaves thrice ternate; leaflets broadly oblong, coarsely serrate : fruit ovate, 2-3 lines long; oil-ducts large, $3-4$ in the intervals ; seed-section pentagonal (figs. 29, 30). Rich ground, S. Pennsylvania to Kentucky and southward. Fl. July and August.

TIEDEMANNIA DC.-Fruit ovate to obovate, flattened dorsally : carpels with 5 primary equidistant ribs ; dorsal and 
intermediate filiform; lateral extended into broad wings, closely contiguous to those of the other carpel, forming a winged margin to the fruit, nerved dorsally at the inner margin, giving the appearance of five filiform ribs on the back of each carpel; strengthening cells under each rib and nerve: oil-ducts solitary in the intervals, $2-6$ on the commissural side: seed-section oblong to broadly oval: stylopodium short, thick, conical (figs. 3I-36).-Smooth erect aquatic herbs, with leaves reduced to petioles or of few narrow leaflets, involucre and involucels present, and white flowers. Eastern species. Including Archemora DC.-Bentham and Hooker have included both Tiedemannia and Archemora under Peucedanum. They are very distinct in habit from our own Peucedanums, which are low dry ground western forms, with much dissected leaves and mostly yellow flowers. The fruit characters still further confirm this difference of habit, the carpels being much more flattened dorsally in Peucedanum, giving a narrow seed-section, the lateral wings nerved ventrally (on commissural side) instead of dorsally, thus giving the appearance of but 3 filiform ribs on the back of each carpel, the stylopodium depressed or wanting instead of conical, and no involucre. These characters seem sufficient not only to separate Tiedemannia and Archemora from Peucedanum, but to unite them into a single genus. No fruit character can be made to separate them, and the only distinction would have to be drawn from the leaves, and this breaks down in the intermediate Archemora ternata. So many salient characters unite Tiedemannia and Archemora, and so few can be made to separate them, that it seems best to conPeucedanum, single genus, and one well distinguished from Peucedanum, at least in North America. Archemora Fend. leri of the south-west is probably not a member of the genus.

I. T. teretifolia DC. Mem. Umbel. 51, t. I2. Stem hollow, 2-6 feet high: leaves reduced to cylindrical hollow pointed modose petioles : oil-ducts filling the intervals, $2-4$ on comisiana. Fl. Augus. 31, 32).-Virginia to Florida and Lou2. T. ternata. Stem September.

with linear entire leaflets, slender, 2 feet high: leaves ternate, times reduced to a flat-tipped lower long petioled, or someon commissural side (fit-tipped petiole: oil-ducts smaller, 4 -North Carolina to (figs. 33, 34). Archemora ternata Nutt. 3. T. rigida. Stem Florida. F1. November.

with $3-9$ linear to lanceolate feet high: leaves simply pinnate, 
oil-ducts small or sometimes large, 4-6 on commissural side (figs. 35, 36) Archemora rigida DC.-New York to Minnesota and south to the Gulf. Fl. August.

PEUCEDANUM L.-Fruit roundish to oblong, much flattened dorsally: carpels with 5 primary ribs; dors 91 and intermediate filiform and approximate; lateral extended into broad wings, closely contiguous to those of the other carpel so as to form a winged margin to the fruit, strongly nerved ventrally (on commissural side) at the inner margin; strengthening cells under each rib and nerve: oil-ducts $\mathrm{I}-3$ in the intervals, $2-6$ on the commissural side: seed-section much flattened (figs. 37, 38).-Dry ground acaulescent (or short caulescent) herbs, with fusiform roots, dissected leaves, no involucre, mostly yellow (sometimes white) flowers, and stylopodium depressed or wanting. Western species.-The strong nerve on the commissural face of the lateral wings seems to be a constant and distinctive character, taking the place of the dorsally placed nerve on the lateral wings of Tiedemannia.

I. P. nudicaule Nutt. Torr. \& Gray, Fl.i.627. Low, nearly acaulescent, pubescent : leaves much dissected: flowers white: fruit nearly round, 2-3 lines broad; oil-ducts small, solitary in the intervals, $2-4$ on the commissural side.-Minnesota to Iowa and westward. Fl. in earliest spring.

PASTINACA L.-Fruit oval, very much flattened dorsally: carpels with 5 primary ribs; dorsal and intermediate filiform; lateral extended into broad wings contiguous to those of the other carpel, strongly nerved towards the outer margin; strengthening cells continuous about the seed cavity and under the nerves : oil-ducts small, solitary in the intervals, $2-4$ on the commissural side: seed-section very much flattened: stylopodium depressed (figs. 39, 40).-Tall stout biennial, with pinnately compound leaves, mostly no involucre, and yellow flowers.

I. P. sativa L. Stem grooved: leaflets ovate to oblong, cut-toothed.-Introduced everywhere. Fl. July-September.

Bentham and Hooker include Pastinaca under Peucedanum, although the fruit characters are quite distinct and almost identical with those of Heracleum. In fact, were it not for the remarkable petals of Heracleum and its conical stylopodium Pastinaca could not be distinguished from it. In comparison with Pencedanum the fruit of Pastinaca is 
much more dorsally flattened, the lateral wings are strongly nerved towards the outer margin, instead of at the inner margin on the commissural side, and a remarkable layer of strengthening cells completely invests the seed cavity, instead of occurring in small isolated groups beneath each rib, all of which characters are shared with Heracleum. As of minor importance the habit of Pastinaca is not that of Peucedanum, but rather that of Heracleum. Pastinaca is thus characterized by the fruit and habit of Heracleum and the floral character of Peucedanum, and had better stand as an intermediate genus. The length of the oil-ducts, a character sometimes used, is far from constant. In Peucedanum they are generally as long as the fruit; in Pastinaca sometimes as long and sometimes shorter; in Heracleum generally about half as long, though sometimes nearly as long.

HERACLEUM L.-Fruit oval, somewhat narrowed at base: like Pastinaca, but with thick conical stylopodium (figs. $4 \mathrm{I}, 42$ ). - Tall stout perennial, with ternately compound leaves, deciduous involucre, white flowers, and obcordate

I. H. lanatum Michx. Fl. i. I66. Woolly, stem grooved: leaflets broad, irregularly cut-toothed.-Wet ground, throughout the northern states, and as far south as North Carolina and Kentucky ; also westward. Fl. June.

Explanation of Plate III.-Figures $27,29,37,39,41$, are $\times 4$; figures $31,33,35$, are $\times 6 \frac{1}{2} ;$ all cross sections are $\times 20$.

\section{A Botanical Tramp throngh North Carolina.}

\section{GERALD M'CARTHY.}

After spending some five or six days in botanizing in the Tar river country, I shipped my presses, etc., by wagon, to Newberne, about forty-five miles farther south, and followed on foot, with portfolio and box, prepared to collect along the way. The road over which my route lay extended for the and cypress swamps. These swastes through a series of gum recent heavy rains, and were now aggregated into one vast quagmire. Long stretches of the road were covered, often to a depth of three feet, by the coffee-black water of the connected the places was crossed by deep streams, which connected the basins of the different swamps. Bridges are 


\section{$2 \mathrm{BHL}$ Biodiversity Heritage Library}

Coulter, John Merle and Rose, J. N. 1887. "Notes on Umbelliferæ of E. United States. III." Botanical gazette 12(4), 73-76. https://doi.org/10.1086/326099.

View This Item Online: https://www.biodiversitylibrary.org/item/90524

DOI: https://doi.org/10.1086/326099

Permalink: https://www.biodiversitylibrary.org/partpdf/221659

\section{Holding Institution}

Missouri Botanical Garden, Peter H. Raven Library

\section{Sponsored by}

Missouri Botanical Garden

\section{Copyright \& Reuse}

Copyright Status: Public domain. The BHL considers that this work is no longer under copyright protection.

This document was created from content at the Biodiversity Heritage Library, the world's largest open access digital library for biodiversity literature and archives. Visit BHL at https://www.biodiversitylibrary.org. 